\title{
INFEKSI PADA VAGINA (VAGINITIS)
}

\author{
Luh Putu Prihandini Utami ${ }^{1}$, Ni Putu Dewi Sri Wahyuni \\ ${ }^{1}$ Prodi Kedokteran, Universitas Pendidikan Ganesha \\ ${ }^{2}$ Prodi Kedokteran, Universitas Pendidikan Ganesha
}

e-mail: prihandini@undiksha.ac.id, sriwahyuni@undiksha.ac.id

\begin{abstract}
Abstrak
Infeksi pada vagina sering dikenal dengan istilah vaginitis. Penyebab vaginitis, $70 \%$ diantaranya disebabkan oleh bakterial vaginosis, candidiasis, dan trikomoniasis. Sedangkan sisanya 30\% dapat disebabkan oleh faktor lain seperti penurunan estrogen. Vaginitis terjadi pada wanita yang telah memasuki fase pubertas maupun akan memasuki fase menopause dengan faktor resiko berupa kurangnya higenitas, hubungan seksual tanpa pengaman dengan banyak pasangan, penyakit menular seksual, dan lainnya. Gejala dan ciri khas masing-masing tipe vaginitis dapat dibedakan berdasarkan gambaran discharge yang dihasilkan serta kondisi fisik dari vagina. Dalam menentukan diagnosis dari vaginitis dapat dilakukan pemeriksaan penunjang berupa pengukuran $\mathrm{pH}$ vagina, kriteria amsel, whiff test, dan mikroskopi menggunakan $\mathrm{KOH}$ dan saline. Pengobatan vaginitis dapat dilakukan dengan pemberian obat topical ataupun sistemik sesuai dengan tipe penyebab vaginitis. Penyakit infeksi vagina ini tidak sampai menyebabkan kematian. Namun apabila tidak ditangani dengan tepat dapat menimbulkan komplikasi, berupa radang panggul, servisitis mukopurulent, selusitis vagina, kemudian apabila dialami oleh ibu hamil dapat menyebabkan keguguran, ketuban pecah dini, kelahiran premature, korioamnionitis, dan infeksi cairan ketuban. Prognosis pada penyakit vaginitis ini umumnya baik dan hampir semua dapat disembuhkan, namun yang patut diwaspadai adalah vaginitis yang berulang atau recurrent karena dapat menyebabkan komplikasi. Pencegahan vaginitis dapat dilakukan dengan tindakan menjaga higenitas vagina serta penggunaan pengaman saat berhubungan seksual.
\end{abstract}

Kata kunci: Vaginitis, Gejala, Tatalaksana

\begin{abstract}
Vaginal infections are often known as vaginitis. The cause of vaginitis, $70 \%$ of them are caused by bacterial vaginosis, candidiasis, and trichomoniasis. While the remaining $30 \%$ can be caused by other factors such as decreased estrogen. Vaginitis occurs in women who have entered the puberty phase and will enter the menopause phase with risk factors such as lack of hygiene, unprotected sexual intercourse with multiple partners, sexually transmitted diseases, and others. The symptoms and characteristics of each type of vaginitis can be distinguished based on the resulting discharge and physical condition of the vagina. In determining the diagnosis of vaginitis investigations can be carried out in the form of measurement of vaginal $\mathrm{pH}$, amsel criteria, whiff test, and microscopy using $\mathrm{KOH}$ and saline. Treatment of vaginitis can be done by giving topical or systemic drugs according to the type of cause of vaginitis. This vaginal infection does not cause death. However, if not handled properly can cause complications, such as pelvic inflammation, mucopurulent cervicitis, vaginal selusitis, then if experienced by pregnant women can cause miscarriage, premature rupture of membranes, premature birth, chorioamnionitis, and amniotic fluid infections. The prognosis for vaginitis is generally good and almost all can be cured, but what should be wary of is recurrent vaginitis because it can cause complications. Prevention of vaginitis
\end{abstract}


can be done with measures to maintain vaginal hygiene and use of protection during sexual intercourse.

Keywords : Vaginitis, Symptom, Treatment

\section{PENDAHULUAN}

Vagina merupakan organ genital interna pada wanita yang memiliki panjang sekitar 7-10 cm. Organ ini berbatasan dengan uretra dan kandung kemih pada bagian anterior, otot levator ani serta fascia endopelvic pada bagian lateral, dan rectum pada bagian posterior. Secara histologis dinding vagina tersusun atas 3 lapisan yakni lapisan mukosa dengan epitel squamous non keratin, dibawahnya terdapat lapisan tunika muskularis yang tersusun atas otot lurik dan otot polos, lapisan terakhir terdapat lapisan adventitia yang kaya akan kolagen dan elastin(Cohen, 2019). Vagina berfungsi untuk menghubungkan alat kelamin luar dengan rahim, sebagai jalan keluarnya janin, serta sebagai saluran ekskresi pada saat wanita mengalami menstruasi (Utama, 2017).

Dalam kondisi normal, pada vagina hidup mikrobiota ( mikroorganisme yang hidup pada organ maupun jaringan tertentu) yang berfungsi untuk melawan invasi dari patogen asing. Umumnya mikrobiota vagina normal terdiri atas kumpulan mikroorganisme aerob maupun anaerob. Namun $90 \%$ mikrobiota vagina itu tersusun atas Lactobacilli. Lactobacilli berperan penting dalam melindungi ekosistem vagina dari serangan patogen melalui produksi lendir dan senyawa antimikroba seperti asam laktat dan hidrogen peroksida (Graziottin, 2015). Asam laktat hasil dari metabolisme glikogen inilah yang kemudian akan mengatur kadar keseimbangan $\mathrm{pH}$ pada vagina agar tetap berada pada rentang normal yaitu 3,8 - 4,4 (Mendling, 2016). Perubahan yang terjadi pada $\mathrm{pH}$ (tingkat keasaman) vagina dapat disebabkan oleh adanya mikrobiota pathogen yang hidup dan menginfeksi ekosistem vagina, contohnya adalah Bakterioides spp dan protozoa parasit $T$. Vaginalis (O'Hanlon, 2013). Efek infeksi dari patogen tersebut dapat menimbulkan rasa ketidaknyamanan dan rasa sakit serta gangguan fungsi organ tersebut. Namun infeksi pada vagina tak hanya disebabkan oleh dua faktor diatas, infeksi juga dapat terjadi akibat jamur ,alergi , dan iritasi.

Infeksi yang terjadi pada vagina ini sering disebut dengan Vaginitis. Dikatakan bahwa, $50-75 \%$ wanita akan mengalami vaginitis, satu kali dalam hidupnya. Penyebab utama vaginitis $70 \%$ umumnya adalah akibat bakteria vaginosis, candidiasis vulvovaginal dan trikomoniasis dengan presentase $40-50 \%$ pasien vaginitis akibat bakteria vaginosis, $20-25 \%$ akibat candidiasis vulvovaginitis, dan 15-20\% akibat trichomonas vaginitis (Roby, 2019). Sedangkan $30 \%$ pasien kemungkinan menderita vaginitis akibat atrophic vaginitis, vaginitis inflamasi deskuamatif, dan penyakit erosif vagina (Neal, 2019). Vaginitis memang tidak sampai menimbulkan kematian, namun apabila seorang wanita mengalami vaginitis dapat mengakibatkan hilangnya rasa percaya diri, terbatasnya fungsi seksual, bahkan depresi yang efeknya akan sangat berpengaruh pada aktivitas sosial individu tersebut (Raphaelidis, 2015). Melihat latar belakang tersebut, penulis ingin membahas lebih dalam mengenai penyakit infeksi pada vagina secara lebih terperinci dan jelas, agar para wanita dapat mengetahui dan membedakan macam-macam penyebab infeksi pada vagina berdasarkan gejala yang dialami, serta dapat mengobatinya dengan mandiri dan tepat.

\section{HASIL DAN PEMBAHASAN}

Vaginitis merupakan penyakit yang sering di alami pasien wanita, penyakit ini memiliki beragam variasi etiologi dan pengobatan, namun umumnya gejala yang ditumbulkan masing-masing faktor penyebab vaginitis sama. Bakterial Vaginosis merupakan salah satu penyebab vaginitis, dimana merupakan suatu keadaan terjadinya perubahan pertumbuhan flora 
pada ekosistem vagina, yang umumnya didominasi oleh bakteri Lactobacillus digantikan oleh mikroorganisme anaerob yang dominan seperti Gardnerella vaginalis, Prevotella, Peptostreptococcus, Megasphaera, Leptotrichia, Sneathia, Bifidobacterium, Dialister dan tiga spesies Clostridium yang dikenal sebagai bakteri yang terkait dengan BV 1-3 Bacteroides spp (Turovsky, 2011). Diagnosis Bakterial vaginosis sering kali dikaitkan dengan gangguan pada saluran reproduksi. Patogenesis BV diawali dengan masuknya bakteri-bakteri tersebut melalui hubungan seksual, infeksi akibat operasi seperti histerektomi, atau akibat higenitas yang kurang dalam merawat ekosistem vagina. Bakteri tersebut kemudian akan menempel pada permukaan vagina dan mulai melepaskan campuran asam lemak rantai pendek, seperti asam butirat dan suksinat, yang dapat memodulasi respons imun dengan memberikan efek negatif yang dapat mempengaruhi kemotaksis neutrofil dan monosit serta aktivitas fagositosis. Bakteri tersebut juga memproduksi amina biogenik yang dapat memfasilitasi dominasi bakteri vagina BV pada vagina(Nasioudis, 2016).

Pada kasus BV akibat bakteri Gardnella Vaginalis, bakteri tersebut memproduksi sitolisins yang menyebabkan kematian sel, serta sialidase, profil, dan putresin, yang dapat memainkan peran dalam menurunkan faktor pelindung mukosa seperti musin (Onderdonk, 2016). Zat besi, seng, dan mangan merupakan nutrisi penting bagi bakteri ini, nutrisi tersebut yang akan berpengaruh pada laju reproduksinya. Tubuh kemudian akan merespon zat-zat tersebut melalui respon imun yaitu dengan dikeluarkannya antimikrobial peptide seperti Cathelicidin yang hadir dalam bentuk sekresi vaginal yang kemudian bertindak sebagai racun dan menginduksi migrasi neutrofil dan monosit atau makrofag dan mengaktifkan sel-sel inflamasi untuk melepaskan sitokin proinflamasi.

Sebelum dikeluarkannya respon imun, epitel pada permukaan vagina terlebih dahulu memberikan respon berupa pengelupasan sel-sel epitel untuk mengeluarkan mikroorganisme yang melekat pada permukaan epitelnya. Selain menghilangkan bakteri yang melekat, pelepasan sel-sel epitel vagina yang kaya glikogen menguntungkan bagi lactobacilli selaku tuan rumah dengan menyediakan sumber nutrisi untuk lactobacilli, yang juga membantu tubuh dalam melawan bakteri patogen melalui pengeluaran bakteriosin serta menjaga keseimbangan $\mathrm{pH}$ vagina . Sehingga eksistensi dari Bacterial vaginosis dalam ekosistem vagina dapat dikendalikan.(Nasioudis, 2016).

Candidiasis Vulvovaginitis merupakan penyebab kedua paling sering terjadinya vaginitis. Candida albicans merupakan penyebab yang sering ditemukan pada 70$90 \%$ kasus. Namun dapat juga disebabkan oleh Candida glabrata, Candida tropicalis, Candida parapsilosis, dan Saccharomyces cerevisiae. Tanda dari infeksi Candida ditandai dengan terbentuknya keputihan yang tebal serta bercak-bercak putih seperti keju. Patogen ini dapat masuk kedalam ekosistem vagina setelah seorang wanita mengalami menstruasi pertamanya. Hal ini terjadi akibat adanya peningkatan hormon estrogen yang menyebabkan peningkatan glikogen pada vagina. Selain itu juga dapat terjadi pada wanita dengan penggunaan antibiotik spectrum luas, mengidap diabetes mellitus, serta infeksi HIV (Quan,2010). Untuk mengidentifikasi spesies Candida dapat dilakukan dengan penggunaan spesimen $\mathrm{KOH}$. Masuknya Candida kedalam ekosistem vagina salah satunya dapat dimulai dari adanya bakteri ini pada bagian perineum area perianal, yang kemudian akan masuk melalui hubungan sexual, kemudian menempel pada epitelium vagina. Selain itu, lingkungan dan higenitas wanita juga dapat mempengaruhi adanya Candida pada vagina (Mills, 2017).

Pada ekosistem vagina, awalnya Candida Albicans akan berbentuk bulat telur (Y), kemudian berubah menjadi organisme dengan hifa berbentuk $(H)$. Umumnya bentuk Y dari Candida Albicans ini bersifat komensalisme, sedangkan untuk bentuk $\mathrm{H}$ lebih bersifat pathogen. Ketika berada diekosistem vagina, epitel vagina akan menghambat bentuk $Y$ tersebut agar tidak berubah bentuk menjadi $\mathrm{H}$. Ketika mekanisme pertahanan tidak dapat menekan perubahan bentuk tersebut, 
bentuk $Y$ akan berubah menjadi hifa, hifa $(\mathrm{H})$ ini kemudian akan membentuk biofilm yang kuat, melekat, dan akan menyerang epitel vagina. Sel-sel epitel akan dilisiskan oleh hifa dan kemudian bersama sel inflamasi akan membentuk cairan vagina yaitu keputihan sebagai tanda dan gejalan dari vulvovaginal candidiasis . Adanya serangan pathogen ini menyebabkan munculnya respon imun pada vagina. Dikeluarkannya sel dendritik (DC), T-helper, limfosit pengatur dan sitotoksik, B-limfosit dan sel pembunuh alami yang menghasilkan sitokin pelindung dan kemokin yang berperan dalam melavan invasi dari patogen ini agar tidak semakin luas.

Selain itu sel epitel juga berperan penting dalam melawan pathogen ini. Selsel epitel vagina tidak hanya merupakan penghalang mekanis dan penangkap dengan bahan permukaan seperti musin dan keratin. , namun juga dapat mendeteksi bahaya yang ditimbulkan oleh patogen dan merespons dengan aktivasi sel dan sekresi mediator imun yang memicu peradangan dan respons imun. Kompleks multiprotein intraseluler, yang disebut 'inflamasi', menerjemahkan sinyal bahaya yang terkait dengan patogen atau produknya ke dalam aktivasi kekebalan. Rekrutmen sel polimorfonuklear ke vagina, sitokin (terutama IL-1b dan IL-18) produksi dan aktivasi subset limfosit T-helper 1 dan (dengan beberapa kontroversi) T-helper 17 telah dikaitkan dengan peran dalam antiperlindungan Candida. (Cassone, 2014).

Trikomoniasis Vaginitis merupakan infeksi menular seksual yang umum dialami oleh seorang wanita. Penyebabnya adalah akibat infeksi dari Trichomonas vaginalis yang dapat masuk akibat hubungan seksual atau lingkungan dan ekosistem vagina yang kurang higenis. Organisme ini merupakan tropozoit flagela, dengan lima flagela yang berperan membantu motilitasnya, tropozoit ini juga dapat berbentuk ameboid ketika bersentuhan dengan inang dan berbentuk pseudokista pada suhu dingin (Lewis, 2014). Patogenesis Trichomonas Vaginalis diawali dengan masuknya protozoa ini ke dalam ekosistem vagina yang kemudian akan menempel pada epitel vagina. Setelah itu ia akan melilsiskan dan memakan sel inang untuk mendapatkan nutrisi makanan.

Trichomonas vaginalis mengeluarkan berbagai macam zat untuk dapat terus melekat pada epitel vagina. Lipoglikan pada permukaan Trichomonas vaginalis merupakan penyebab protozoa ini mampu bertahan melekat sekaligus mampu mematikan sel inang atau epitel vagina. Zat protease yaitu sitokin protease dan protein palmitoilasi juga dianggap penting dalam perlekatan Trichomonas vaginalis pada epitel vagina. Protease yang dihasilkan dari protozoa ini sangat membatu dalam merusak epitel vagina. Sama seperti mekanisme sebelumnya masuknya trichomonas vaginalis ini kemudian akan merangsang tubuh untuk mengeluarkan respon imun guna menghilangkan keberadaan trichomonas vaginalis pada ekosistem vagina.(Mercer, 2018).

Athropic Vaginitis. Vaginitis ini terjadi akibat berkurangnya kadar serum estrogen . Reseptor estrogen, alfa dan beta, diekspresikan di seluruh epitel skuamosa, jaringan ikat dan otot polos vulva, vagina, uretra, dan trigonum kandung kemih dan sangat penting untuk memediasi berbagai fungsi biokimia dan fisiologis reproduksi wanita . Dengan hilangnya stimulasi estrogen, perubahan besar terjadi dalam mukosa vulvovaginal dan urogenik. Hasil dari perubahan ini adalah hilangnya elastisitas mukosa keseluruhan dan penipisan sel epitel vagina. Menipisnya lapisan pada epitel vagina menyebabkan permukaan vagina sangat rentan terhadap infeksi sekunder patogen lain. Terjadinya penipisan sel epitel dapat menyebabkan penurunan kadar glikogen yang kemudian akan berakibat pada penurunan lactobacilli yang berperan sebagai mikrobiota pelindung ekosistem vagina, sehingga dapat meningkatkan pertumbuhan bakteri patogen. Selain itu penurunan esterogen juga menyebabkan vagina kehilangan rugae, terjadinya distensibilitas, dan ada pemendekan dan penyempitan vagina. Mukosa vagina, introitus, dan labia minora menjadi tipis, pucat, dan kering. Vaskularisasi pada daerah sekitar vagina juga dapat berkurang. Kita ketahui bahwa vagina tidak mempunyai sel goblet dan tidak menghasilkan mucus sendiri, cairan sekresi vagina merupakan transudat dari 
pembuluh darah disekitarnya, oleh karena itu apabila kadar serum esterogen menurun jumlah dan konsistensi mukosa vagina juga ikut menurun (Stika, 2010). Vaginitis ini dapat juga disebut sebagai vaginitis hipoestrogenik. Vaginitis ini biasanya dialami oleh wanita yang telah mencapai fase menopause. Dapat terjadi karena berbagai faktor seperti, ooforektomi, kontrasepsi oral, serta obat anti estrogenik (Neal,2019).

Di dalam vagina wanita yang telah mengalami menopause atau premenopause akan terdapat bakteri Doderlein lactobacillus yang berperan sebagai flora dominan, dan memiliki kemampuan untuk mengubah glikogen menjadi asam laktat yang kemudian akan menjaga keseimbangan $\mathrm{pH}$ vagina. Selain itu hidrogen peroksida juga dihasilkan, kombinasi keduanya akan membantu menekan potensi infeksi vagina akibat patogen lain .

Faktor lain selain status estrogen yang dapat mempengaruhi keparahan gejala genital adalah wanita yang tidak pernah melahirkan melalui vagina. Wanita yang melahirkan tidak melalui persalinan per vaginam cenderung lebih bergejala daripada wanita yang telah mengalami peregangan vulvovaginal. Kondisi penurunan estrogen ini dapat diperburuk oleh aktivitas merokok dengan menurunkan perfusi genital dan selanjutnya mengurangi ketersediaan estrogen dalam mukosa vulvovaginal. Seperti yang telah dijelaskan sebelumnya bahwa esterogen berperan penting untuk tetap menjaga ekosistem vagina dari pertumbuhan mikrobiota patogen.(Stika, 2010).

Vaginitis Inflamasi Deskuamatif merupakan vaginitis non infeksi yang khas dan menyakitkan.Vaginitis ini jarang dialami oleh wanita, cirinya adalah ruam pada vagina, produksi cairan purulen yang berlebih serta timbulnya rasa sakit yang berulang atau terus-menerus. Etiologi vaginitis ini tidak diketahui dan sering tidak terdiagnosis. Apabila dilihat secara mikroskopik epitel vagina menunjukkan adanya peningkatan yang nyata pada selsel inflamasi, terutama leukosit polimorfonuklear dan sel epitel parabasal, bersama dengan peningkatan flora vagina abnormal (Sobel, 2011).

Kriteria untuk menetapkan diagnosis vaginitis ini terdiri dari ada tidaknya infeksi dan stenosis pada vagina, ada tidaknya vaginitis purulen eksudatif, ditemukannya tanda-tanda pengelupasan epitel, $\mathrm{pH}$ vagina meningkat, serta pada pewarnaan gram ditemukan bakteri gram positif cocci dimana pada keadaan normal seharusnya terdapat bakteri gram positif bacilli. Tidak seperti vaginitis atrofi, gangguan ini tidak responsif terhadap terapi estrogen. (Bradford, 2010).

Beragam faktor resiko dapat menyababkan terjadinya penyakit infeksi vagina ini, umumnya vaginitis terjadi pada wanita setelah memasuki fase pubertas atau memasuki fase menopause. Karena vaginitis dapat dialami oleh setiap wanita dengan minimal satu kali episode vaginitis dalam kehidupannya maka dari itu patut kiranya wanita mewaspadai faktor-faktor berikut.

Pada bakterial vaginosis dapat dialami oleh individu dengan sosial ekonomi yang rendah, sering membersihkan vagina dengan cairan antiseptic atau pewangi, merokok, melakukan hubungan seksual tanpa pengaman, melakukan hubungan seksual dengan lebih dari satu partner, serta personal hygine yang kurang. Untuk faktor resiko dari candidiasis vulvovaginitis dapat disebabkan akibat penggunaan antibiotic spectrum luas, mengidap diabetes melitus, adanya infeksi HIV, serta adanya penggunaan kortikosteroid dan imunosupresan jangka panjang.

Untuk faktor resiko dari trikomoniasis vaginitis sendiri dapat disebabkan oleh tindakan sex bebas, penggunaan narkoba, merokok, melakukan hubungan seksual tanpa pengaman, adanya penyakit infeksi seksual menular pada pasangan, serta personal hygine yang kurang. Faktor resiko athropik vaginitis dapat terjadi pada wanita yang telah mengalami menopause, laktasi, tindakan ooforektomi, terapi radiasi, kemoterapi, adanya gangguan imunologis, gangguan endokrin, serta konsumsi obat antiestrogen.

Sedangkan vaginitis inflamasi desquamatif. dapat terjadi pada wanita perimenopause, wanita seksual aktif, hubungan seksual tanpa pengaman, 
melakukan hubungan seksual dengan lebih dari satu partner, serta personal hygine yang kurang. (Hainer, 2011). Dapat dilihat dari faktor-faktor tersebut sebagian besar disebabkan oleh pola hidup wanita yang kurang sehat. Kebiasaan-kebiasaan buruk tersebut dapat menyebabkan terjadinya pergeseran $\mathrm{pH}$ vagina, berkurangnya Lactobascilus sp. sebagai flora normal vagina, sehingga menyebabkan pertumbuhan berlebih dari mikrobiota patogen yang ada di vagina. Kemudian faktor resiko dari tiap etiologi vaginitis ini cenderung serupa antara satu dengan yang lainnya, untuk itu pemeriksaan penunjang diperlukan guna menegakkan diagnosis infeksi vagina ini.

Setiap jenis vaginitis memiliki manifestasi klinis yang hampir mirip dengan satu sama lain, namun tetap terdapat faktor pembeda yang membedakan tipe-tipe vaginitis tersebut. Hal ini tergantung dari etiologi penyebab vaginitis. Umumnya ciri dari vaginitis adalah keluarnya cairan berbau, rasa gatal, dan dispareunia atau rasa sakit terus menerus pada vagina.

Gejala atau manifestasi klinis yang dialami pasien dengan bakterial vaginosis umumnya adalah adanya keputihan yang abnormal dengan bau amis, pruritus, serta iritasi. Ciri khas dari bakterial vaginosis adalah adanya keputihan dengan warna putih atau abu-abu yang terlihat pada dinding samping vagina dengan pemeriksaan spekulum (Mills, 2017) Dapat dilihat pada gambar 1. Sedangkan manifestasi klinis seseorang yang mengalami vaginitis akibat candidiasis dapat dilihat pada gambar 2 adalah ditemukannya keputihan yang kental dalam jumlah banyak dan gatal, terasa pegal, disuria eksternal, dan dispareunia. Terdapat kemerahan, pembengkakan dan eritema vagina yang dapat dilihat pada pemeriksaan fisik. Ciri khas dari candidiasis adalah adanya bercak-bercak keputihan yang putih seperti keju. PH vagina biasanya normal. Tidak ada bau ketika sekresi vagina dicampur dengan $10 \% \mathrm{KOH}$ (tes bau). Pemeriksaan penunjang untuk candidiasis vulvovaginitis adalah dengan pemeriksaan mikroskopis epitel vagina dalam saline atau dalam $10 \% \quad \mathrm{KOH}$ karena dapat mengungkapkan adanya ragi atau miselia yang mulai tumbuh. Selain pemeriksaan mikroskopis kultur bakteri juga dapat digunakan untuk membantu menegakkan diagnosis. (Mills, 2017).

Untuk trikomoniasis vaginitis, gejala dan tanda trikomoniasis umumnya tidak spesifik, dan diagnosis dapat dilakukan dengan menggunakan mikroskop. Tanda dari trikomoniasis adalah terlihatnya trichomonas vaginalis dengan saline pada mikroskop, leukosit juga terlihat lebih banyak daripada sel epitel, apabila dilakukan Whiff test hasilnya positif, dan $\mathrm{pH}$ vagina didapatkan lebih tinggi dari 5,4. Ciri khasnya adalah keputihan abnormal yang berwarna kuning kehijauan, adanya dispareunia, nyeri dan gatal vulvovaginal, serta nyeri saat buang air kecil, eritema vulvovaginal, keluarnya cairan, dan kadangkadang perdarahan pada mukosa vagina dan serviks (Mills, 2017), dapat dilihat pada gambar 3.

Pada athropic vaginitis manifestasi klinis yang dapat terjadi adalah adanya dispareunia, vagina kering, gatal, rasa terbakar, cairan purulen, eritema vagina, dan petekia. Dapat dilihat pada gambar 4 Pada atropik vaginitis $\mathrm{pH}$ vagina akan meningkat di atas 4,5. Ciri khasnya adalah pada pemeriksaan mikroskop terlihat mukosa vagina yang tipis dengan lapisan yang lebih sedikit akibat penurunan kadar serum esterogen (Neal, 2019).

Untuk vaginitis inflamasi deskuamatif manifestasi klinis dari vaginitis tipe ini adalah terjadinya dispareunia berat, pruritus, iritasi , erosi dengan batas yang jelas, dapat dilihat pada gambar 5. Lesi muncul dalam pola yang terlihat linier, dan kadang-kadang terdapat ekimosis, $\mathrm{pH}$ lebih tinggi dari 5. Ciri khasnya adalah keputihan purulen dan ruam pada vagina, serta adanya peningkatan sel inflamasi (neutrofil) ,dan kurangnya dominasi Lactobacilli ketika dilakukan pemeriksaan dengan menggunakan mikroskop (Mills, 2017). 


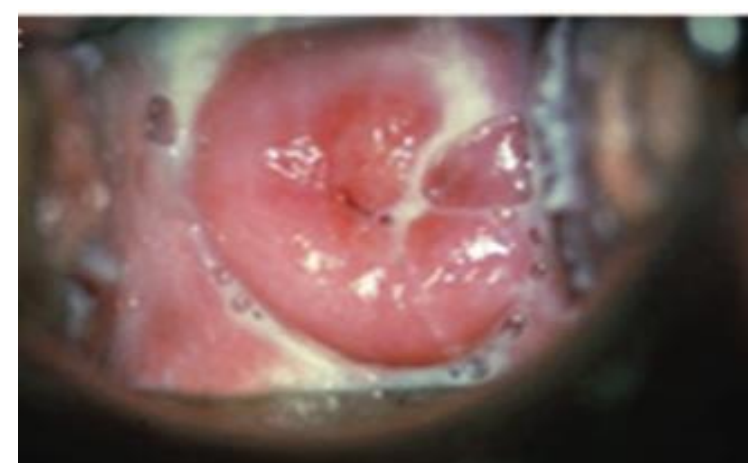

Gambar 1. Menunjukkan gambaran discharge pada vaginitis bakterial vaginosis (Paavonen dan Brunham, 2018)

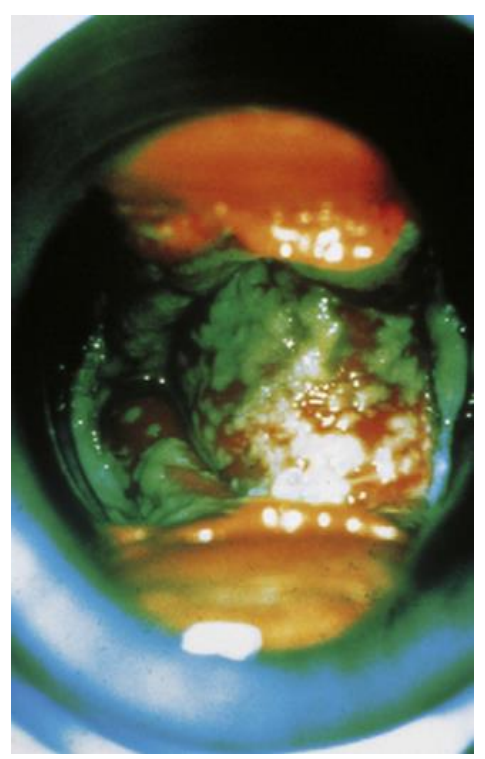

Gambar 2. Menunjukkan gambaran discharge pada candidiasis vulvovaginitis (Sobel, 2014)

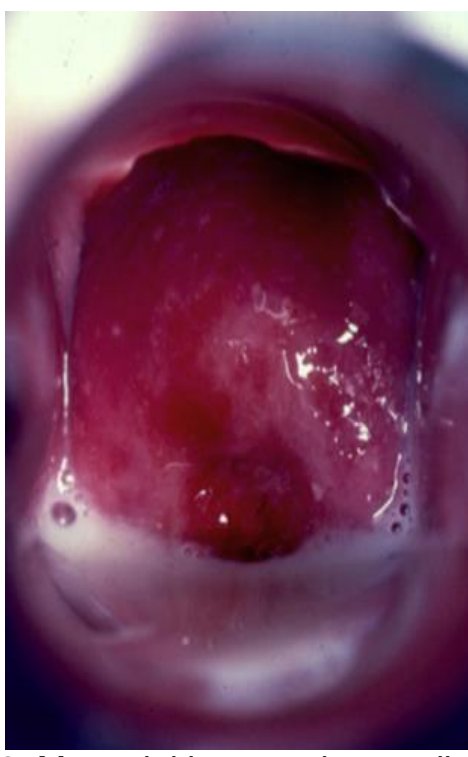

Gambar 3. Menunjukkan gambaran discharge pada trikomoniasis vaginitis(Lewis, 2014)

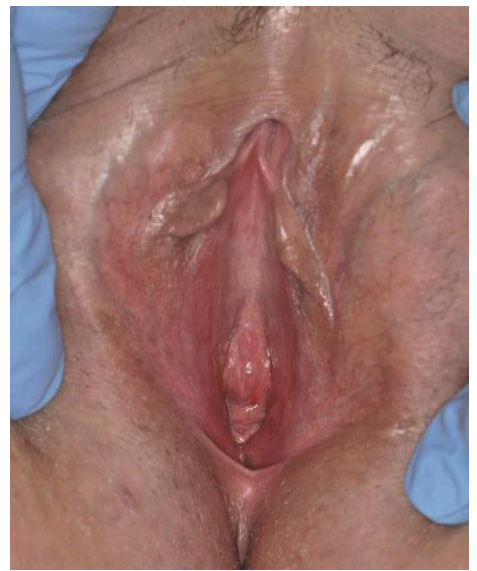

Gambar 4. Menunjukkan gambaran vagina pada atropik vaginitis (Stika, 2010)

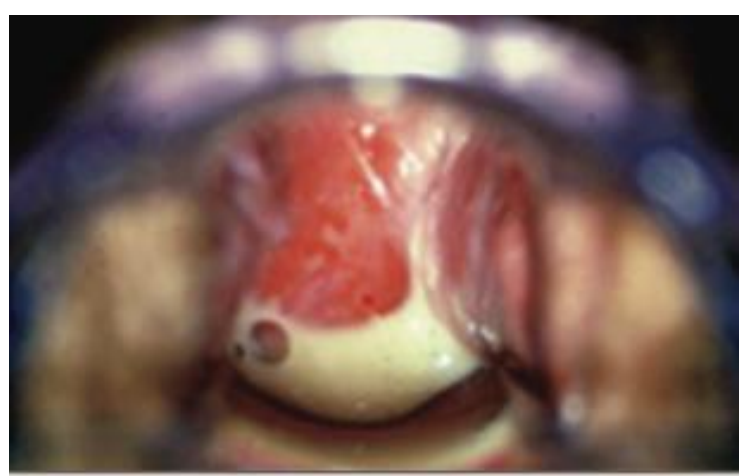

Gambar 5. Menunjukkan gambaran discharge pada vaginitis inflamasi deskuamatif (Paavonen dan Brunham, 2018)

Perbedaan pada etiologi setiap jenis vaginitis, mengharuskan seorang wanita yang diduga memiliki gejala vaginitis, untuk melakukan sejumlah pemeriksaan penunjang guna menegakkan diagnosis vaginitis tersebut. Berikut merupakan pemeriksaan penunjang yang hendaknya dilakukan guna mengetahui etiologi atau penyebab pasti vaginitis pada wanita sehingga dapat dilakukan pengobatan yang tepat.

Pemeriksaan penunjang yang dapat dilakukan oleh seorang wanita adalah pemeriksaan dengan kriteria Amsel. Kriteria Amsel berguna dalam penegakan diagnosis pada wanita yang diduga mengalami bacterial vaginosis. Kriteria tersebut diantaranya adalah adanya peningkatan keputihan yang tipis dan homogeneous atau berwarna putih seperti susu, $\mathrm{pH}$ vagina lebih dari 4,5, terdapat bau amina ketika larutan kalium hidroksida 10\% ditambahkan ke setetes cairan vagina serta kehadiran sel 
petunjuk dalam preparat basah. Apabila seorang wanita mengalami 3 dari 4 kriteria tersebut dapat dipastikan mengalami bakteral vaginosis (Mohammadzadeh, 2014).

Kedua, pengukuran $\mathrm{pH}$ vagina. Pengukuran $\mathrm{pH}$ penting dilakukan, karena umumnya infeksi yang terjadi pada vagina menyebabkan $\mathrm{pH}$ vagina meningkat, dari yang mulanya normal sekitar 3,8-4,4, naik menjadi diatas 4,5 . Test $\mathrm{pH}$ ini dilakukan dengan mencelupkan $\mathrm{pH}$ strip pada cairan vagina, kemudian amati perubahan warna yang terjadi, umumnya rentangan $\mathrm{pH}$ tersebut 0 hingga 6 . Test ini dapat dilakukan untuk pada tiap jenis vaginitis, serta memiliki biaya yang terjangkau dalam pelaksanaannya (Mills, 2017)

Ketiga, Whiff Test. Test ini hampir mirip dengan ph test, dimana untuk mengetahui penyebab infeksi diperlukan swab vagina terlebih dahulu guna mengambil spesimen cairan vagina, kemudian cairan diletakkan pada kaca preparat dan diteteskan $10 \%$ potassium hydroxide $(\mathrm{KOH})$, kemudian dilakukan penilaian terhadap baunya, dikatakan positif apabila timbul bau amis atau fishy odor. Keuntungan melakukan uji Whiff test adalah bahwa tes ini dapat dilakukan tanpa spekulum, dan penggunaan antibiotik dapat dibatasi. Tetapi dibandingkan dengan pemeriksaan spekulum, whiff test tidak akan dapat mendiagnosis kondisi seperti servisitis, erosi serviks dan PID. Hasil uji pH dan uji Whiff sebanding dengan uji mikroskop dan tes ini lebih hemat biaya serta memakan waktu lebih sedikit dibandingkan dengan uji mikroskop. (Damke, 2016).

Keempat, mikroskopi dengan saline atau $\mathrm{KOH}$. Mikroskop dapat digunakan untuk mengetahui mikrobiota yang terkandung dalam cairan vagina guna menegakkan diagnosis, dilakukan dengan mengambil specimen cairan vagina kemudian diletakkan dipeparat dan diteteskan saline atau $10 \% \mathrm{KOH}$ kemudian diamati pertumbuhan mikrobiota pathogen didalamnya lewat mikroskop. Apabila lactobacilli ditemukan sedikit atau bahkan tidak ada dapat menjadi pertanda adanya infeksi disebabkan oleh bacterial vaginosis atau vaginitis inflamasi deskuamatif, kemudian apabila ditemukan protozoa motil dengan flagella dan lebih banyak sel leukosit dibanding epitel, kemungkinan disebabkan oleh trichomoniasis. Jika ditemukan fillamen yang dirangkai oleh ragi serta terdapat miselium dapat menjadi pertanda adanya infeksi vulvovaginal candiasis, apabila pada mikroskop mukosa vagina lebih sedikit dibanding jumlah normalnya dapat menjadi pertanda adanya atropik vaginitis.(Mills, 2017).

Kelima, kultur mikrobiologi. Kultur bakteri penting dilakukan untuk mengetahui mikrobiota patogen penyebab infeksi dan keberlimpahannya, studi virulensi, kerentanan antibiotik, dan urutan genomnya sehingga memudahkan dalam pemahaman dan pengobatan penyakit yang disebabkan oleh mikrobiota patogen. Kultur dilakukan dengan membiakkan mikroorganisme pada medium tertentu. Dalam pelaksanaan kultur mikrobiologi terdapat variasi mulai dari waktu inkubasi, nutrisi, media, atmosfer, dan suhu yang disesuaikan dengan kebutuhan yang diperlukan.

Untuk tatalaksana masing-masing jenis vaginitis berbeda-beda disesuaikan dengan etiologi vaginitis tersebut. Berikut merupakan beberapa obat-obatan yang dapat digunakan dalam mengobati vaginitis.

Tabel 1. Tatalaksana Vaginitis

\begin{tabular}{lrl}
\hline Tipe Vaginitis & \multicolumn{1}{c}{ Obat } & Dosis \\
\hline Bakterial Vaginosis & Konsumsi umum : & \\
& 1. Metronidazole $500 \mathrm{mg}$ tabet & $500 \mathrm{mg}$ 2x sehari dalam 7 hari \\
2. Metronidazole $0,75 \%$ gel & $5 \mathrm{gr}$ setiap hari dalam 5 hari \\
3. Clindamycin $2 \%$ cream & $5 \mathrm{gr}$ saat waktu tidur dalam 7 hari \\
4. Tinidazole $2 \mathrm{gr}$ tablet & $2 \mathrm{gr}$ sehari untuk 2 hari \\
5. Tinidazole $1 \mathrm{gr}$ tablet & $1 \mathrm{gr}$ sehari untuk 5 hari \\
6. Clindamycin $300 \mathrm{mg}$ tablet & $300 \mathrm{mg} 2 \mathrm{z}$ sehari selama 7 hari \\
& 7. Clindamycin $100 \mathrm{mg}$ ovule & 1 ovule pada waktu tidur dalam 3 hari \\
\hline
\end{tabular}




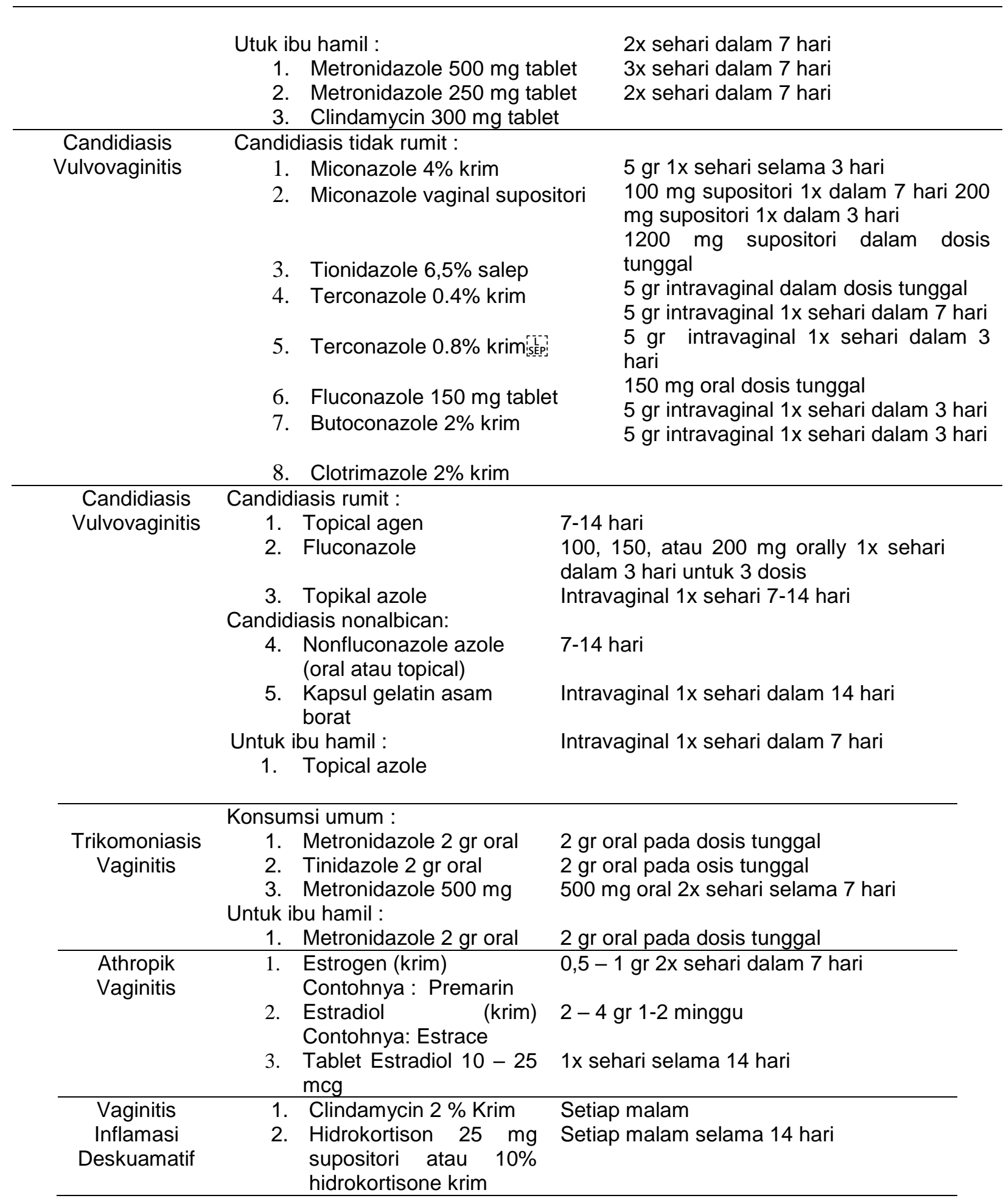

Vaginitis merupakan penyakit umum yang sering dialami oleh wanita, umumnya penyakit infeksi ini tidak sampai menyebabkan kematian. Namun apabila tidak ditangani dengan tepat dapat menimbulkan komplikasi. Pada wanita yang mengidap bakterial vaginosis dapat terjadi komplikasi berupa radang panggul, servicitis mukopurulent, selusitis vagina, kemudian apabila dialami oleh ibu hamil dapat menyebabkan keguguran, ketuban pecah dini, kelahiran premature, korioamnionitis, dan infeksi cairan ketuban. Trikomoniasis vaginitis juga memiliki resiko tinggi terhadap penyebab terjadinya keguguran pada ibu hamil, kelahiran 
premature, serta karioamnionitis. Pada wanita biasa trichomonas vaginitis dapat menyebabkan neoplasia serviks, radang panggul, infertilitas tuba, serta faktor resiko penularan virus HIV (Quan, 2010). Pada infeksi candidiasis vulvovaginitis apabila tidak ditangani dengan baik dapat menyebabkan kondisi paling parah dan kronis yang dikenal sebagai candidiasis vulvovaginitis berulang (Cassone, 2014). Pada athropic vaginitis dapat menyebabkan iritasi vagina atau vulva, kondisi dermatologis vulva seperti lichen planus atau peradangan pada kulit dan selaput lendir, lichen sklerosis yaitu bercak putih pada kulit daerah genital, dan vulvodinia yaitu nyeri kronis pada lubang vagina. Pada vaginitis inflamasi deksuamatif komplikasi yang dapat terjadi adalah timbulnya keputihan purulen terus-menerus disertai rasa nyeri (Roby, 2019).

Prognosis pada penyakit vaginitis ini umumnya baik dan hampir semua dapat disembuhkan apabila diberikan pengobatan yang tepat serta konsumsi obat dengan teratur oleh pasien, pengobatan juga hendaknya diberikan sedini mungkin agar tidak sampai menimbulkan komplikasi, namun yang patut diwaspadai adalah terjadinya vaginitis yang berulang atau recurrent karena dapat menyebabkan peningkatan terjadinya komplikasi.

Hal-hal yang perlu dilakukan seorang wanita untuk mencegah penyakit infeksi pada vagina ini dapat melalui tindakantindakan yang berkaitan dengan kebersihan atau higenitas vagina. Karena kita ketahui bersama umumnya infeksi terjadi pada vagina dengan higenitas yang relative rendah, meskipun demikian tak menutup kemungkinan ada faktor lain juga yang dapat memicu terjadinya vaginitis. Oleh karena itu penting sekali bagi wanita untuk menjaga kebersihan vagina dengan cara rutin mebersihkan vagina setiap mandi dengan arah dari atas kebawah atau tangan tidak sampai mengenai anus, rutin mengganti pembalut setidaknya $4 x$ sehari ketika menstruasi, menggunakan pakaian dalam yang tidak terlalu ketat dan usahakan berbahan dasar kapas, sehingga mudah menyerap keringat. Mengeringkan daerah kewanitaan dengan baik sehabis mandi atau buang air kecil, sehingga tidak lembab, usahakan agar tetap kering. Tidak menggunakan pembersih kewanitaan yang terlalu banyak mengandung bahan kimia. Mencukur bulu kemaluan agar tidak terlalu lebat karena dapat menyebabkan ekosistem vagina menjadi lembab. Kemudian menggunakan pengaman berupa kondom bila melakukan hubungan seksual, hindari seks bebas, lakukan hubungan seksual yang aman. Pencegahan yang dilakukan ini berupaya agar patogen penginfeksi tidak dapat masuk kemudian tumbuh dan berkembang serta merusak ekosistem vagina (Sumarah,2017).

\section{KESIMPULAN}

Vaginitis merupakan penyakit infeksi pada vagina yang umum dialami oleh wanita. Infeksi ini dapat disebabkan oleh berbagai macam penyebab. Untuk memastikan penyebabnya, terdapat berbagai macam test yang dapat dilakukan. Gejala dari penyakit ini umumnya berupa keputihan abnormal, bau vagina yang tak sedap, rasa nyeri pada saat kencing ataupun berhubungan seksual, serta gatal. Vaginitis tidak akan membahayakan apabila ditangani dengan tepat. Pengobatan yang diberikan haruslah sesuai dengan penyebab yang ada. Namun tidak menutup kemungkinan akan terjadi infeksi berulang serta komplikasi apabila pengobatan yang diberikan tidak tepat, ketidak patuhan pasien dalam mengkonsumsi obat yang diberikan, serta gaya hidup pasien yang kurang bersih dan sehat. Vaginitis dapat dicegah dengan cara menerapkan gaya hidup bersih dan sehat sehingga dapat menjaga dan meningkatkan kebersihan serta higenitas ekosistem vagina.

\section{DAFTAR PUSTAKA}

Bradford, J., \& Fischer, G. 2010. Desquamative Inflammatory Vaginitis. Journal of Lower Genital Tract Disease, 14(4), 306-310.

Cassone, A. 2014. VulvovaginalCandida albicansinfections: pathogenesis, immunity and vaccine prospects. BJOG: An International Journal of Obstetrics \& Gynaecology, 122(6), 785-794.

Cohen Sacher, B. 2019. The Normal Vulva and Vagina. Vulvar Disease, 7-19. 
Damke, S. S., Fule, R. P., \& Tankhiwale, N. S. 2016. Utility of $\mathrm{Ph}$ and whiff test for screening of abnormal vaginal discharge among women of reproductive age in rural area. International Journal of Current Research and Review, 8(10), 33.

Graziottin, A., \& Gambini, D. 2015. Anatomy and physiology of genital organs-women. In Handbook of Clinical neurology (Vol. 130, pp. 3960). Elsevier.

Hainer, B. L., \& Gibson, M. V. 2011. Vaginitis: diagnosis and treatment. American family physician, 83(7), 807-815.

Lagier, J.-C., Edouard, S., Pagnier, I., Mediannikov, O., Drancourt, M., \& Raoult, D. 2015. Current and Past Strategies for Bacterial Culture in Clinical Microbiology. Clinical Microbiology Reviews, 28(1), 208236.

Lewis, D. 2014. Trichomoniasis. Medicine, 42(7), 369-371.

Mendling, W. 2016. Normal and abnormal vaginal LaboratoriumsMedizin, 40(4).

Mills, B. B. 2017. Vaginitis. Obstetrics and Gynecology Clinics of North America, 44(2), 159-177.

Mohammadzadeh, F., Dolatian, M., Jorjani, M., \& Alavi Majd, H. 2014. Diagnostic Value of Amsel's Clinical Criteria for Diagnosis of Bacterial Vaginosis. Global Journal of Health Science, 7(3).

Neal, C. M., Kus, L. H., Eckert, L. O., \& Peipert, J. F. 2019. Non-Candidal Vaginitis: $A$ Comprehensive Approach to Diagnosis \& Management. American Journal of Obstetrics and Gynecology.

O'Hanlon, D. E., Moench, T. R., \& Cone, R. A. 2013. Vaginal $p H$ and Microbicidal Lactic Acid When Lactobacilli Dominate the Microbiota. PLOS ONE, 8(11), e80074.

Paavonen, J., \& Brunham, R. C. 2018. Bacterial Vaginosis and
Desquamative Inflammatory Vaginitis. New England Journal of Medicine, 379(23), 2246-2254.

Quan, M. 2010. Vaginitis: Diagnosis and Management. Medicine, 122(6), 117-127.

Raphaelidis, L. 2015. Uncommon Vaginitis Cases: Expect the Unexpected. The Journal for Nurse Practitioners, 11(1), 135-138.

Roby, K. F. 2019. Vaginitis. Reference Module in Biomedical Sciences.

Sobel, J. D., Reichman, O., Misra, D., \& Yoo, W. 2011. Prognosis and Treatment of Desquamative Inflammatory Vaginitis. Obstetrics \& Gynecology, 117(4), 850-855.

Sobel, J. D. 2014. Genital candidiasis. Medicine, 42(7), 364-368.

Stika, C. S. 2010. Atrophic vaginitis. Dermatologic Therapy, 23(5), 514522.

Sumarah, S., \& Widyasih, H. 2017. Effect of Vaginal Hygiene Module to Attitudes and Behavior of Pathological Vaginal Discharge Prevention Among Female Adolescents in Slemanregency, Yogyakarta, Indonesia. Journal of family \& reproductive health, 11(2), 104.

Turovskiy, Y., Sutyak Noll, K., \& Chikindas, M. L. 2011. The aetiology of bacterial vaginosis. Journal of Applied Microbiology, 110(5), 11051128.

Utama, B. I., \& Ermawati, E. 2017. Septum Vagina Transversa. Andalas Obstetrics and Gynecology Journal, 1(2), 68-72. 